\title{
Re-Narrating Mariel: Black Cubans, Racial Exclusion, and Building Community in Miami
}

\author{
Devyn Benson ${ }^{1}$ and Danielle Clealand ${ }^{2}$ \\ ${ }^{1}$ University of Kentucky, US \\ ${ }^{2}$ University of Texas at Austin, US \\ Corresponding author: Danielle Clealand (danielle.clealand@austin.utexas.edu)
}

The wave of migrants that arrived in South Florida from Mariel is a familiar story among Cubans, but popular and scholarly understandings of the exodus still exist without sufficient regard for how race mattered for who would be sponsored by families, who would be able to assimilate, and who would benefit from the Cuban enclave. Our essay shows, through oral histories, that Black Mariel migrants were less likely to find jobs and housing and experienced marginalization at higher levels than white Mariel migrants, most often from fellow white Cubans. Our narration centers racial identity in the analysis in ways that depart from much of the literature on the Mariel migration by not only freeing Black stories and perspectives, but recognizing that whiteness, even among a stigmatized group, must be considered. We bring Black people into the story of this migration, not just as a part of racial statistics and stigma, but as people whose real-life experiences remain largely hidden. In this way, we not only show how they were excluded, but celebrate community building and strategies to overcome exclusion.

Keywords: Black Cubans; Afro-Cuban; Mariel; Cuba; Cuban Americans; racism; racial discrimination; Afro-Latinos; race

In 1980, Sergio Arrechea arrived in Miami as a high school student via the Mariel Boatlift and began working with his father, Barbarito Arrechea, a Black Cuban property owner in Overtown who had settled in the city in the late 1960s. Arrechea Sr. learned that Black Cubans who migrated as "Marielitos" did not have the same access to housing as those who were white. Black migrants were most often denied rentals in the Cuban enclave of Little Havana (and other Southwest areas), which were specifically created to provide these very opportunities. Arrechea Sr. began renting to Black Cubans and soon his Overtown properties earned their nickname, the "Cuban buildings," to contrast their new residents with the majority Black American occupied housing in the neighborhood. Sergio described how his father came to own these buildings and his decision to rent to Afro-Cubans because they could not rent elsewhere:

My father started collecting rents in Overtown in the late 1960s for a Jewish property owner and little by little he saved enough to buy his own building in 1975. It was very difficult [for a Black Cuban] to arrive at an apartment and say, "I'm going to rent this place." You'd have to send a Cuban, a Cuban that was lighter than you or white because if not, there was no other way to rent ... The buildings had about 18 apartments and after Mariel, there came a point where he had two buildings full and none of the apartments were occupied by Americans. So, they started to call them the Cuban buildings. I don't know what the laws were about housing discrimination, but white Cubans were discriminating against Black Cubans. (Arrechea)

Although Arrechea rented his property to new migrants in Overtown, Black Cubans and Black Americans living alongside each other in Overtown and elsewhere were part of a then two-decade old pattern fomented by structural legacies of redlining, exclusion by white co-ethnics, and continued housing segregation in Miami. Black folks of all ethnic backgrounds lived together, but while non-Cuban Black people were kept out 
of white residential spaces, Black Cubans were excluded from their own Cuban enclave. ${ }^{1}$ Eventually many white Cubans that arrived via the Mariel Boatlift integrated into the larger Cuban community, but Black Cubans continued to be characterized as outsiders in those same spaces. This is particularly significant as other analyses of the Cuban experience in Miami (and of Latinos in general) have often portrayed a racially homogenous community. Most discussions of the successful Cuban enclave, before and after 1980, do not include the requirement for inclusion: whiteness.

As over one hundred thousand Cubans descended upon Miami from the Mariel Boatlift in 1980, the city entered a crisis. City, state, and federal officials devised various plans to process and house the migrants that were fleeing the Cuban Revolution. The wave of migrants that arrived in South Florida from Mariel differed demographically from previous waves of Cuban migration, particularly in its higher number of nonwhites. Scholars have advanced varied narratives about the Mariel exodus, whether focusing on the demographics of the migrant wave, the stigma the migrants carried, the solidarity Cuban Americans showed to the new migrants, or the trajectories of Mariel migrants in the labor market. ${ }^{2}$ Mariel is a familiar story among Cubans, too, but popular understandings of the exodus still exist without regard for how race mattered for who would be sponsored by families, who would be able to assimilate, and who would benefit from the Cuban enclave. Paradoxically, Black Mariel migrants' experiences are often absent from the stories Cubans and academics tell, but they are hyper-visible in characterizations of a Blacker, criminal population. Thus, in Mariel narratives-scholarly and popular-Black experiences are invisible, even as the Black presence is widely understood to have defined the image of the migrants.

Mariel Cubans that came to the United States were stigmatized as criminal, mentally ill, and/or homosexual. ${ }^{3}$ The criminalization of Mariel was not disconnected from the statistics that showed $10-40 \%$ of the migrants were nonwhite. ${ }^{4}$ While characterizations of criminality were grossly exaggerated, they were used to describe the new migrants, regardless of their racial background. Consequently, scholarship focused on Mariel recognizes this stigma, but only some scholars have addressed the racialization of the Mariel refugees. The universalism of the negative characterizations was not the only cause for Black people to be invisibilized, as Black lives have historically been erased from what we deem Hispanic, Latino, and Cuban. ${ }^{5}$ Thus, the irony and uniqueness of Mariel scholarship to date lies in the recognition of Blackness without delving into an analysis of how Black refugees actually fared during this experience. ${ }^{6}$ Much of the literature avoids the discussion of racism rather than examining how being Black often determined outcomes, which in turn racially homogenizes Mariel migrants. In doing so, this literature privileges whiteness and contributes to the continued invisibilization of Black Cubans. Using oral histories, we re-narrate the Mariel experience through the lens of Black people that arrived in 1980.

As the story of the Arrechea family shows, practices of racial exclusion and anti-Blackness in general were prevalent in the Cuban community before the new wave of migrants arrived in 1980, but they were reinforced as the media began to talk about and show "Marielitos" as darker-skinned, with a criminal element. This pattern of anti-Black exclusion persisted and resulted in different experiences as refugees were being processed in camps in South Florida and other locations throughout the country. Black Mariel migrants were less likely to be sponsored by families and had different experiences than white Mariel migrants as they navigated housing, schools, socialization, and jobs in their new country. ${ }^{7}$ This pattern of exclusion and othering, we argue, shows that not only were "Marielitos" racialized, but so were the solidarity and humanitarian efforts among Cuban Americans when asked to house families and support the new migrants. Many Black Cubans were never sponsored by families and as a result were left to live in poor conditions at Fort Chafee; those remaining by 1982 were either transferred to halfway houses or sent to federal prison where the U.S. government left them indefinitely without charges, grossly violating their human rights. ${ }^{8}$

As a result of exclusion by co-ethnics, a particular consciousness about Blackness that began in 1959 continued to develop, building Black Cuban community solidarity and alternative political attitudes when

\footnotetext{
${ }^{1}$ Aguirre analyzes the motivations for Black Cubans to primarily reside in the Northeastern part of the United States, citing not only Jim Crow policies, but anti-Blackness among Cuban Americans.

2 Bach et al.; Clark et al.; Bach, Portes, Clark \& Manning; Card; Aguirre; Hamm 1991; de los Angeles Torres; Pedraza; Eckstein; Burga.

${ }^{3}$ See Fernández 2002 and Masud Piloto.

${ }^{4}$ See Clark et al.; Garcia; Pedraza.

${ }^{5}$ See Flores and Jiménez Román.

${ }^{6}$ For exceptions to this pattern see Gosin; Fernández 2002; López 2010; and Aja.

See Aja; Gosin

${ }^{8}$ See Fernández 2002; Triay.
} 
compared to white Cubans. We describe the ways that Black folks found community through shared social networks, religion, and the solidarity of experience. Black Cuban social cohesion was partially built from common residential spaces, where many lived in the Northwest area of Miami, particularly in Allapattah, or gathered there. Together they created a Black cultural world that was largely unknown to white Cubans and provided some freedom from being othered in Miami. In this way, Black Cubans' solidarity networks and social unity mirrored many of the practices of Black Americans that were born out of U.S racial marginalization.

Our essay is derived from a larger project that, through oral histories, maps the experiences, stories, politics, and strategies of Black Cuban migrants after the Cuban Revolution in 1959, including those that arrived during Mariel. Our narration centers racial identity in the analysis in ways that depart from much of the literature on the Mariel migration by not only freeing Black stories and perspectives, but recognizing, that whiteness, even among a stigmatized group, must be considered. Our oral histories highlight how white Cubans were able to access whiteness in Miami and in turn excluded their own Black co-ethnics during and before Mariel, thereby redefining and reinforcing racial exclusion. We explore these dynamics through the experiences, memories, trajectories, activism, and community building experiences of Black Mariel migrants themselves. Intra-Latino racism and whiteness in the Cuban community are seldom recognized, and it can be neater to gloss over racial difference. ${ }^{9}$ The tendency embraces the long-established Latin American ideology of racial democracy, which negates the presence of racism in exchange for an image of racial harmony, often to hide hierarchical racial realities. ${ }^{10}$ The actualities of anti-Black racism have never been so neat for Black Mariel migrants. We highlight patterns of exclusion and bring Black people into the story of this migration, not just as a part of racial statistics and stigma, but as people whose real-life experiences remain largely hidden.

\section{Using Oral History to Narrate Black Lives}

Highlighting experiences of Black Cuban discrimination and racial solidarity in response to white exclusion-both during and before the Mariel Boatlift-conflicts with the usual portrayal of Cuban and Cuban American experiences in South Florida. Existing historical narratives privilege the establishment of the Cuban ethnic enclave in the 1960s, its economic success, and the retention of Cuban culture, making Miami a Latino city where Cubans established themselves politically and eventually carved out a nonracialized (white) identity. Indeed, the first two waves of Cuban migration were majority white, and race, specifically whiteness, played a major role in the success of the enclave. ${ }^{11}$ While we argue that the privilege that Cubans received as migrants during the first two waves is tied to whiteness, we also acknowledge that this access was vulnerable to discrimination from Anglo Miamians. ${ }^{12}$ There was a dual process by which Cubans received access to white spaces such as schools, but also experienced initial rejections from these white spaces. Structurally, however, white Cubans were able to live their lives as white people within the system of Jim Crow and following this period where its institutional presence continued to affect Black Miamians. Moreover, the federal funding, resettlement assistance, and (de facto) political asylum they received were all connected to racial privilege. Studies such as Boswell and Curtis's The Cuban American Experience (1984) and Maria Cristina García's Havana USA: Cuban Exiles and Cuban Americans in South Florida, 1959-1994 (1996), highlighted the successes of the earliest exiles and examined how that success led Cubans to frequently be called a model minority. García notes that the goal of her book is to write a history of the "formation of community ... Whenever possible, I have tried to let the émigrés speak for themselves to provide a sense of the human drama of migration and to demonstrate the process of identity formation and cultural negotiation" (2). Cubans did indeed build a strong community and identity in Miami in particular. However, membership into the community was often based on race. Our work offers a different narrative that centers Black Cubans who were forced to create their own alternative community that could survive without the resources of the white enclave and its networks.

Narratives about Mariel often highlight how Cuban immigrants arriving in 1980 experienced significantly more discrimination from both Americans and Cubans in South Florida than previous waves of Cuban immigrants. ${ }^{13}$ Yet much of the scholarship has failed to recognize how white Mariel Cubans still had access to more power and privilege than their Black counterparts. Previous scholarship that examined the stigma that

\footnotetext{
${ }^{9}$ See Aja; Gosin; Lopez 2010.

${ }^{10}$ See Sawyer; Clealand.

${ }^{11}$ The first wave of migration, 1959 to 1962, constituted the initial exodus from the Revolution and the second wave, from 19651973 , constituted those that came primarily through the freedom flights.

${ }^{12}$ See Gosin.

${ }^{13}$ See Eckstein; Fernández 2007; Skop.
} 
"Marielitos" faced did not connect that stigma to Blackness and anti-Black stereotypes. ${ }^{14}$ Monika Gosin's The Racial Politics of Division: Interethnic Struggles for Legitimacy in Multicultural Miami is one of the few recent works to challenge this racially homogenous Mariel narrative. Through interviews of Afro-Cubans in Miami and Los Angeles, Gosin (2019) examines the experience of Black Cubans who arrived in 1980. She argues that the media took the "stigma for granted" rather than explore, as she does, "how the stigma came into being through a language around Blackness" (20). In her analysis of Mariel news coverage in the Miami Herald and El Miami Herald, she finds that nearly half of the stories discussed the stigma and criminality of the migrants, but only one out of hundreds makes note of the more difficult situation for Black Mariel migrants. Gastón Fernández (2002) and Alan Aja (2016) are two scholars who also have argued that race is essential to understanding the stigma surrounding the Mariel migrants. Nonetheless, oral histories hold the unique power to release the silence and invisibility of Blackness and allow for migrants that were not white to tell their stories. Most often, these stories highlight not only the insularity of the Black Cuban communities in South Florida, but also the structural patterns that affected most Black Cubans in remarkably similar ways.

From the end of 2018 to 2021 we collected 100 oral histories of Black Cuban migrants and secondgeneration Cubans ranging in age (18 to 96) as well as socioeconomic class, level of education, region, generation, and time of arrival. Our project uncovers experiences beginning in 1959 to the present, mapping structural patterns of exclusion that led to the creation of a Black Cuban identity in South Florida. Oral histories offer an opportunity for Black Cubans to provide new data, their data, regarding their experiences as first- and second-generation immigrants, to create a critical counter archive. Additionally, unlike most scholarship on Cuban Americans that does not recognize Blackness among migrants until 1980, we highlight the continuity between the experiences of Black Cubans who arrived in the 1960s and 1970s and those who arrived during Mariel as a means of disrupting the conventional wisdom about the origins of this community. In this way, we place Mariel in its historical context and reframe the archive to consider Blackness from the start of the Cuban Revolution and not just with Mariel. ${ }^{15}$ Nonetheless, the stories of Mariel migrants detained in camps for extended periods of time, sent to halfway houses and sent to federal prison, suggest that migrating to the United States during Mariel presented significant challenges that Black migrants prior to 1980 did not experience.

Oral history represents the best method available to rescue stories of Black Cubans in the United States and to understand race and racism within the exile community both before and after Mariel. In order to capture people's experiences during and following migration, interviewing is essential. ${ }^{16}$ Moreover, to understand political socialization in Cuba and the United States, choices about housing and schooling, and family backgrounds that led to these decisions, we needed family stories. Like other oral history practitioners, we recognize the link between oral history and memory where memory is both "the subject as well as source of oral history."17 These histories show narrators actively making meaning out of their past as a means of identity/self-making. As such, oral historian Valerie Yow highlights how memory researchers have shown that significant foundational memories and those attached to deep emotion, such as memories of youth, young adulthood, and in this case migration, remain largely consistent over time (See Yow pp. 42-47). When paired with other oral histories (a collective or public remembering of the same event) and archival materials like newspaper and other print media, census records, and photographs, the oral histories of Black Mariel migrants collected here become powerful sources about an invisible past.

Our research also makes the argument that oral history should figure more prominently in social science scholarship, particularly in political science, a field where it is seldom used. Oral history as a methodology allows us to understand the why and how regarding existing theories and data about identity politics, voting behavior, Black consciousness, and educational and economic disparities. These histories reveal personal backgrounds, socioeconomic positions, and familial experiences. Finally, stories of migration incorporate entire families and for that reason we interview both first and second generations to map how the experiences of migration and racial exclusion affected social mobility and political socialization in the children of immigrants.

\footnotetext{
${ }^{14}$ See Boswell \& Curtis; Masud-Piloto; and Omar Granados' essay in this issue where, through oral histories of the experiences of Black and mulato Mariel migrants that were held at Ft. McCoy, he highlights the failure to document the black experience and makes important connections between accusations of criminality and race during the Mariel exodus.

${ }^{15}$ For statistics relating to Afro-Cuban socioeconomic indicators compared to white Cubans from 1959 until the present, see Aja.

${ }^{16}$ Oral history provides scholars with a set of tools to locate voices that are not included in traditional archives. This is especially true of often silenced Black communities. For example, see oral histories of Black workers, Black freedom struggles, and Black women in the United States: Honey; Goudsouzian \& McKinney; Brown \& Valk.

17 See Perks \& Thomson and Yow for a discussion of the trustworthiness of human memory.
} 
We used snowball sampling to identify our interviewees, and many of our initial interviews came from members of an Afro-Latino organization co-founded by Danielle Clealand and other Black Latinos. These collaborators then led us to other Black Cubans who were part of various communities in and outside of Miami. Interviews were done in person or via Zoom in Spanish, English, or both languages, and they ranged from one to five hours in length. We asked open ended questions about Black Cuban experiences in Cuba, with migration, and then in the United States, covering themes such as housing, schooling, building community, and politics. We have taken into account the sample's gender, age, and diversity of socioeconomic status to ensure a sample that is representative of the Black Cuban population. Our larger sample of 100 interviews includes oral histories with Afro-Cubans primarily in Miami; however, we also conducted 20 interviews in New York. We chose the New York/New Jersey area as the second largest Cuban population as well as a point of comparison with the Black Latino experience in Miami. For this essay, we selected out the oral histories of Mariel migrants (all of whom live in Miami), but have also included excerpts from the larger sample when necessary to provide context of the larger community into which Black Mariel migrants moved.

Drawing from oral histories, this essay demonstrates how anti-Black racism impacted Black Cubans' reasons for leaving the island, their immigration processes, and their housing and schooling opportunities once in Miami. This exclusion led Black Mariel migrants to seek out and create Black Cuban spaces and communities outside of the ethnic enclave. Through these oral histories, we highlight the ways in which systematic racial segregation and exclusion, entrenched in Miami during the period of Jim Crow, were reinforced by white Cubans as they arrived here. ${ }^{18}$ While white Cubans were able to foster privilege and belonging, they also helped to ensure Miami continued to be an anti-Black city. In order to understand the racial dynamics of 1980 Miami, we must recognize the experience of Black Cubans who arrived during this time and the environment that was solidified before their arrival. Inserting more analysis of race and racism into Cuban Studies is critical as we reevaluate Cuban immigration processes and experiences forty years after Mariel. The continuities seen in this essay between pre- and post-1980 Black Cuban experiences with the white Cuban enclave reveal that anti-Black racism will persist, operate, and shapeshift until we decouple Cubanness from whiteness both on the island and in the United States.

\section{Establishing an Enclave: The First Waves of Cuban Exiles}

The first two waves of Cuban migrants received unprecedented support as an immigrant group with one billion dollars funneled into flights, job training, recertification, resettlement, housing, and small business loans, among other areas. ${ }^{19}$ This group of migrants was majority white, mostly from the professional classes, and arrived in the United States fleeing communism. We hear very little about the Black Cubans that came alongside white Cubans and what their stories are. In fact, the Miami Herald called the Black migrants prior to 1980 an "insignificant part of the refugee influx" (Gugliotta). It is precisely because we know these first two waves to be made up of white migrants that it becomes acceptable not to discuss Black migration in the pre-1980 period and the experiences of Black Cuban migrant families. When the scholarship and the media acknowledge racial diversity among Cuban Americans, it is during the Mariel Boatlift. Blackness in 1980, however, is contextualized alongside the criminal and mentally ill element that came during the exodus into Miami. ${ }^{20}$ Thus, as soon as we hear about Blackness in the Cuban community, it is being criminalized. The history of Cuban migration, then, is often presented as a juxtaposition between the golden exiles of the 1960s and the less educated, less wealthy, darker, more problematic migrants than came subsequently.

The Black Cuban presence in South Florida prior to 1980 was not insignificant to their co-ethnics, as they were excluded from the neighborhoods, social networks, and resources the first wave of exiles built. As white Cubans arriving in the early 1960s settled into Miami, they purchased buildings in the Southwest area and created the Cuban enclaves of, initially, Little Havana and, later, Hialeah. Owners living in these neighborhoods routinely refused to rent to Black Cubans. As Maria López details in recalling her search for apartments in the late 1960s and early 1970s:

When we first got married in 1972, we were looking for rentals. My husband would call about an apartment [that was available] and one time when we got there, the woman opened the door and immediately started to step back. She said, "there aren't any available apartments anymore." After a while, there came a point when you know how I would call to look for apartments? I called and said, "listen,

\footnotetext{
18 See Aguirre 1976.

19 See Grenier \& Stepick; Garcia.

20 See Aja; Gosin.
} 
we are Black" ... I like to hit people where it hurts. You need to confront people where they are ... so I would say, "we are a married couple, we have jobs, but we are Black." For that reason, we have always lived in areas that weren't particularly Cuban. We never lived in Hialeah (never) or the Southwest area (Little Havana/Westchester). I don't want to be a part of that; and I've never been a part of that.

Our research shows that, most often, white Cubans were the ones that kept Black Cubans outside of the enclave, preserving it as a white space.

Being offered an apartment over the phone, only to be denied in person once their Blackness was discovered, was a theme repeated in our oral histories with 1960s migrants that continued into the 1980s. The practice developed among Black families where one would ask a lighter skinned friend to inquire in person about an apartment or avoid Cuban neighborhoods altogether. López hoped that by revealing her Blackness before the family got to the door, she would avoid the rejection that often came in person. And while that strategy was not always effective, it created space for her to openly denounce white Cuban prejudice. For the López family, these experiences led them to develop strategies for maintaining their integrity in the face of anti-Black discrimination. Once Maria and her husband built their own business_ _ becoming more financially well-off - they lived in areas where non-Latino whites owned and rented. They found less racism in these areas and did not have trouble purchasing a home.

The federal funds and resources that were channeled into building the Cuban economic enclave allowed for immigrant success, but these resources were also attached to whiteness. None of our interviewees received or had access to the resources provided during the 1960s and many of them had no knowledge of the funding. White Cubans were able to attend white segregated schools and were able to build the first bilingual education program in $1963 .{ }^{21}$ Little Havana, and later Hialeah, became cultural hubs for Cuban residences, restaurants, businesses, and cultural preservation. In time, Cubans were able to not only access whiteness, but own it and reinvent it. The terms "Latino" and "Hispanic" in the city of Miami (and to a lesser degree even the very city of Miami) have become synonymous with whiteness such that Black Latinos are rendered invisible; when they are visible, they are marginalized. ${ }^{22}$

Maria and her family were outliers in our research as they achieved upper-class status and had more choices for housing. Most Black Cubans resided in working-class African American communities as these were the neighborhoods where they were able to purchase or rent homes. The family of David and Deborah Rosemond, for example, were able to purchase a home in Allapattah from a Jamaican family after being shut out of Little Havana (See Rosemond, 2018; Rosemond, 2019). Apartments that were available over the phone, as Maria discusses in her interview above, were no longer available once the Rosemonds came and revealed their Black skin. These oral histories force us to consider how Black Cubans navigated this period and the ways that whiteness among Cubans (and later other Latin Americans) merges Latin American notions of white supremacy with U.S. notions of the same to foster privilege and belonging, reinforcing Miami as an anti-Black city.

In response to being refused housing in white Cuban enclaves, some Black Cubans built their own communities in the 1960s. Allapattah, a neighborhood sitting in between the Cuban space of Little Havana and the predominantly African American space of Liberty City, came to be known as the center of Black Cuban life. Ricardo González argues that "as a result of segregation, a whole neighborhood developed." While he didn't live in Allapattah, he and his friends, two other Black Pedro Pan migrants, socialized there. González recalls meeting his wife in the neighborhood. "I'm not going to say that all of the people were Black, but it's where most of the Black people and Brown people lived. That's where I met my wife, and my friends also socialized there ... My wife's father was relatively wealthy by those standards. He lived there and he was sort of like the center of social activity" (González). González's father-in-law, Adán Jimeno, left Cuba because he had been close to Batista; however, similar to other Black Cubans, he had never planned to come to the United States because, like González's father, he was afraid of the racial discrimination he might face as a Black man. But, after 1959, his position in the Batista administration meant he had to leave.

Black Cubans resisted white exclusion in the 1960s by creating their own spaces, communities, and social lives. Often, this was in response to both white American and white Cuban racism and discrimination. Early Black migrants laid the foundation for Black Cuban communities that were later able to provide support networks, social worlds, and sometimes housing to Black Mariel migrants when they arrived. Yet, the literature

\footnotetext{
${ }^{21}$ See Garcia.

${ }^{22}$ Although we use the term Latino in this essay, the term Hispanic is more often used as the pan-ethnic identifier among Cubans in Miami, which speaks to investment in whiteness and the relationship to Spain.
} 
is mostly silent about how anti-Black racism repeatedly limited Black Cuban opportunities both before and after 1980. The persistence of these exclusionary practices and their existence before Mariel shows how Cuban migration to the United States has from its inception been about whiteness. Tracing the continuity between early waves of Cuban migration and the 1980 boatlift disrupts narratives that try to distinguish the first wave of golden or model minority exiles from those arriving in 1980.

\section{Mariel: Black Motivations and Experiences in Cuba}

Black Cubans who participated in the Mariel Boatlift did so for similar reasons as other Cubans. They entered the Peruvian embassy searching for better economic opportunities, to escape persecution, and/or to join friends and family members who wanted to leave the island or already had migrated. Anti-Black racism and experiences of racial discrimination also contributed to the general discontent Black Mariel migrants faced in Cuba. Although Fidel Castro and the Cuban government were lauded in the first years of the revolution for their attention to dismantling racial segregation and opening spaces for Black Cubans to attend university and enter into the education and health sectors, racism was not eliminated with the start of the revolution. Indeed, once formal and informal segregation were prohibited, the revolutionary government forbid discussion of the continued presence of racism, which prevented further progress toward racial equality. Residential segregation, lack of Black representation in the government and the media, and employment discrimination continued alongside anti-Black racial prejudice that complicated the lives of Black Cubans. ${ }^{23}$ Black Cubans experienced racism on the island and compared to their white counterparts, increased scrutiny and admonishment when outed as future migrants or counterrevolutionaries. Anti-Black racism and white exclusion impacted immigration processes from the very beginning.

Oral histories reveal that a number of Black Cubans joined the Mariel Boatlift in 1980 due to previous experiences of censorship or persecution by Cuban authorities. In the case of Manuel Casanova, a mulato writer from Havana, Cuban editors limited his writing from the start of his career-especially when he wanted to write about racism. "I've always had problems, from the start of my career. The problems that I had were what we call 'bretero.' I liked writing my opinions, what I thought about things. Of course, that is when the difficulties began" (Casanova). By 1968, Casanova says that revolutionary leaders had accused him of being the "leader of Black Power in Cuba." This same year Cuban leaders invited more than four hundred intellectuals from seventy countries to Havana for Cuba's first Cultural Congress. ${ }^{24}$ Casanova remembers being part of a group of young Black intellectuals who wanted to bring up questions about the persistence of racism and discrimination at the Congress. In one of the panels leading up to the Congress, he asked the following questions, "Why are Afro-Cuban religions and religious practitioners who participated heavily in the wars for independence oppressed/restricted? Why is the [Catholic] church, that has always been an instrument of power used against the people, allowed to continue? Why are Blacks persecuted for their religion?" (Casanova). After this interaction, he began to feel the "heat" as government officials watched and followed him. Ultimately, Casanova spent a year and a few weeks in prison because of his persistent anti-racist work and writings, and he knew by the late 1960s and early 1970s that he wanted to leave Cuba.

That opportunity came in 1980 when a neighbor told him how hundreds of Cubans had invaded the Peruvian embassy and invited him to go see what was going on. Casanova, along with Natividad Torres and her brother, Ezequiel Torres, spontaneously packed a suitcase, went to the embassy, and decided to join the group of folks leaving the island (Casanova). Unlike Casanova, Ezequiel Torres had not endured imprisonment for his ideas about race and racism, but he was involved in various hidden activities of Black activism, part of which included thinking about a Black Panther party in Cuba with others in his group. Torres was always aware that there were limited opportunities for Blacks in Cuba. When talking about how much he loved playing basketball, Torres reflected:

The only chance that Black Cubans have in Cuba is to be a musician, an athlete, or a militant in support of the revolution. They don't have other chances. Or they can be poor ... You can stay poor and not talk about anything and stay there [in Cuba] being hungry like a crab in the mud-that's all. And that is what the majority do, the majority of the crabs do this. Living in the mud waiting for lightning to strike or to get stomped on, I guess.

\footnotetext{
${ }^{23}$ See Clealand.

${ }^{24}$ See Salkey; Walmsley pp. 136-138.
} 
Torres' view of the lack of opportunity for Black Cubans was part of his decision to leave. In 1980, on his way home from working at the National School for the Arts, he ran into his neighbor shouting, "Ezequiel, stop messing around, come here, we are going! This is a sure thing!" in reference to the Cubans who had crashed a bus into the embassy. Torres took a moment to sit on the Malecón, and immediately decided he would pack a bag and join his friends in the embassy; he invited his mother and sister to do the same. Ezequiel would become a leader in Afro-Cuban cultural preservation and religion in Miami, a master drum maker and batá player, and he received various cultural awards. (He received the key to the city, the 2008 Florida Folk Heritage Award and the 2010 National Heritage Fellowship.)

For both Casanova and Torres, the decision to go to the embassy happened quickly, but the environment that limited their opportunities as Black men who challenged the Cuban government was not new. Today, Hugo Cancio is a well-known businessman: he is the founder and Editor in Chief of the magazine OnCuba and is President of the Fuego Media group. He comes from a family of Black Cuban entertainers and musicians, who became well known for organizing events and bringing Cuban Timba musicians like Los Van Van to Miami for the first time, amidst significant controversy. However, before immigrating to Miami in 1980 , his family had high hopes that he would deviate from the family musical tradition and become a doctor. Cancio attended a boarding school in Matanzas where he studied medicine and planned to follow in his grandfather's footsteps as a physician. Unfortunately, he told a joke about Fidel Castro one night in his bunk bed and the next day Cuban officials expelled him from school. His mother came and got him from the school and very quickly his father, Miguel Cancio, who was part of the legendary group, Los Zafiros, was stripped of his singing license and had to become a street sweeper. In remembering why her father, Hugo, left Cuba, Cherie Cancio, who was born in Miami, noted that her family had not planned to immigrate to the United States until this incident. My grandmother "loved the United States because she loved Motown music, but she, they, had no reason to leave. They lived in Varadero, their father was a military doctor, they were a prominent Black family there ... There was no need for them to go at that point ... he was expelled and [it] was like, he had no future" (Cancio and Cancio).

As a young Black man of military age, it was not easy for Cancio to leave the island. After being expelled from the medical school, authorities sent him to a military camp. His mother told him to lie and say that he was gay, "because that was the only way, being gay or crazy, that was the only reason he was going to get out of military service," recalls his daughter, Cherie. While at the camp, officials targeted him for being Black. Cherie Cancio recalls her father telling her, "They began giving him newspapers on discrimination happening here [in the United States] towards Black people, the riots that were happening in Miami in the 1980s." They also ridiculed him for being gay.

Cancio's Blackness impacted how the officials interacted with him. They intentionally showed him newspapers about African Americans being discriminated against in the United States to discourage him from leaving. This action fit with moves made by revolutionary leaders in the early 1960s to contrast Cuba's national racial integration campaign with violations police officers committed against Civil Rights protesters in the U.S. South to show Black Cubans how much better life was in Cuba than in the United States. ${ }^{25}$ These interactions affected Cancio to such an extent that he considered not going to the United States because he worried about how he would be treated as a Black man. In the end, his mother's friend put him on a boat, his mother and aunt left on another ship, and the family reunited in Miami. Cancio's father did not leave Cuba until the 1990s because he had remarried and had two other children in Havana. Until his departure, he continued his employment in the only position still available to him, as a street sweeper.

The quick decline in the status of the Cancio family reflects the precariousness of life for Black Cubans in this period. The Cancios had been well-known as musical performers, were the descendants of the first Black senator in Cuba, Martin Morúa Delgado, and lived as professionals in a middle-class neighborhood, but one youthful joke eroded their position in society. Revolutionary leaders expected complete loyalty from Black Cubans because of early 1960s discourses that had positioned Blacks as grateful beneficiaries of revolutionary reforms. When Afro-Cubans told jokes or crossed the line in any way they were persecuted harshly. ${ }^{26}$ The Cancios participated in the Mariel Boatlift not as a family that was openly hostile to revolutionary leaders or the Cuban revolution, but as a family that no longer had other options for economic and social advancement.

Sergio Arrechea was only 16 years old when he boarded a boat at the Port of Mariel to head to the United States. Arrechea knew he wanted to leave Cuba and did not have one singular experience that led to his departure. Nonetheless, he recalls the ways that other Black people were targeted for their decision to leave.

\footnotetext{
${ }^{25}$ See Benson pp. 160-164

${ }^{26}$ See Benson.
} 
Cuban historian Abel Sierra Madero has chronicled how everyday Cubans harassed, shamed, and committed violence against other Cubans who planned to leave during Mariel. ${ }^{27}$ Arrechea remembers these events, called acts of repudiation, were often more likely to target Blacks in his neighborhood. "I know that they did acts of repudiation, the folks from my high school [el pre] ... They didn't tell me about any of that because everyone knew that I was going to leave the country. That was the difference. But I know that things happened in my neighborhood. And, I know they did everything against Black people" (Arrechea). Similarly, Manuel Casanova recounts neighbors in Cuba throwing water on his partner, Natividad Torres, while yelling that she had sold herself for cheap (Casanova). Others describe Cubans throwing eggs at Black Mariel migrants and sometimes this harassment was accompanied by racialized hate speech. Much like the ways the officials in the camp forced Hugo Cancio to read about the acts of violence against African Americans to discourage him from leaving Cuba, racialized acts of repudiation aimed at Black Mariel migrants highlighted the intersections of anti-Black racism, state power, and anti-migration attitudes.

\section{Mariel: Facing U.S. Racism}

Once in the United States, Black Mariel migrants stood out and were targeted by officials, journalists, and white Cubans because of their race. Gastón Fernández (2002) discusses cases in the media finding that one third of all references to the Mariel refugees associated them with convicts and criminals. Michael Daly of New York Magazine linked the criminality to the practice of "Afro-Cuban cults" and as Fernández argues, "the viciousness of the crimes reported, the code words associating the Marielitos with racial stereotypes of black crime, the emphasis on female victims, the connections to drugs and gangs reinforced negative stereotypes" (The Mariel Exodus 32). The anti-Blackness that existed in the Cuban community and the media's criminalization of Black people were both present before the media began to talk about "Marielitos" as criminals. Although Mariel migrants were often criticized and marginalized for their alleged criminality, in both Cuba and the United States, Blackness has historically been criminalized and it was no secret that this third wave of Cuban migration was Blacker than the previous two. ${ }^{28}$ There was also a cyclical process whereby the stigmatization of Mariel migrants led to a lack of resettlement, which produced rebellious actions among those newly arrived Cubans mandated to remain in the camps. Indeed, those sent to camps on military bases were more likely to be single and nonwhite. ${ }^{29}$ In fact, among those that were never resettled, $95 \%$ were Black men who 1) had to continue to endure the conditions at Ft. Chaffee knowing they were likely not sponsored because of their race and 2) eventually were sent to halfway homes or endured appalling human rights violations in prison without charges or trials.

Ezequiel Torres had his first experience with racism as soon as he arrived. "They sent us to Hialeah, to Milander Park and at the park's community center, there were forty families. That was the first experience of racism that I had here ... The reporters were looking for stories for the Miami Herald and they came up to me and said, 'What a decent family you have, what decent Black people. My God, incredible."' The sheer amazement of the journalist to meet a Black family that studied at the university and held professional positions in Cuba reveals the ways that white Cubans and Americans were preconditioned to expect the worst from Black Mariel migrants. These prejudices also played out in how Black Cubans without existing family members in Miami were chosen for sponsorship. Torres recounts how white Cubans were more likely to sponsor and support new white Mariel migrants than Black:

Cubans even gave us tours of their houses while we were living in the [refugee] center. They would take us into the house and say, look how we live. As if to say, we had to emigrate but look how we have prospered. We have three cars; we have three bedrooms. And I said to my sister, I'm not going on any more tours. With anyone. I don't want to see how anyone lives. I want to live my life and don't show me the development of the white Cuban family. Because at that point, we were there for fifteen days. White families would come and ask other white families in the center, "how many are in your family?" And they would say, "we have three children my wife and my mother-in-law" and they would say, "ok look, we will solve your problem. We're going to give you the key to an apartment with two bedrooms and we have a job for you so that you can get ahead. You have a month's rent already paid." After a month, there were no longer any white families.

\footnotetext{
27 See Sierra Madero.

${ }^{28}$ See Clealand.

${ }^{29}$ (Portes et al.; Skop) (Fernandez; Triay). It should be noted that the nonwhite sample used in the Skop (2001) article included those that self-identified as "Other Race," which may or may not be Blacks and mulatos.
} 
Black Mariel migrants spent longer times in refugee camps and were provided fewer resources when they exited than their white counterparts, which directly impacted their opportunities for stability and social mobility. ${ }^{30}$ Both of Torres' interactions fit with how Black Americans and Black Cubans were previously perceived and treated in South Florida: Black Mariel migrants' experiences with racism were quite similar to what Black Cuban migrants experienced in the previous two decades.

Manolo Casanova, Ezequiel's sister's partner, remembers that they found him a sponsor but when the family saw his partner, Natividad Torres, was darker skinned, they backed out. He explains how enraged he was by the racism and felt like Cuban American families treated them like dolphins, wanting to throw balls at them as a prize. Natividad Torres, who became a cultural leader and a leading voice for Afro-Cubans in Miami, discussed racism in Miami often. She worked for Radio Martí and said to the Miami Herald in 2004, "The racism here in Miami is far deeper than anything I knew in Cuba. I am not able to do the sort of shows I want — shows that would celebrate the role of Afro-Cubans in the island's history, in food-in every single aspect of Cuban life, including its Catholicism. There is a whole world Miami cannot bear to admit to" (Hanley). Although Natividad spoke out about anti-Black racism in her community, the platform to do so was often cut off. Unfortunately, Natividad passed away, but her spirit was present in many of our interviews with her family and her legacy as a prominent Afro Cuban activist in Miami is well known by her community.

In addition to employment and housing obstacles, many of the younger Black students from the 1980 boatlift shared experiences of being bullied on account of both being "Marielitos" and being Black Cubans. Milena Sánchez came with her mother at 14 years old and attended Miami Beach High School. She recalls being surprised when the racism that she experienced came from white Cubans and other Latinos, rather than white Americans. Her family rented from an Orthodox Jewish family and felt welcomed by the community as a whole. At school, however, she faced daily bullying from Cuban Americans:

I was taken in by the Black Americans. They were the ones that would shelter me, defend me. Because the kids were always like, "oh the Marielitos." Their favorite pastime after school every day was "lets go beat up on the Marielitos." All the Cubans and the other cultures too; it wasn't just Cubans. And you know, kids at school can be cruel ... this is the cool thing to do. Beat them up. Why? Because they're different. Why? Because they don't speak English. Why? Just because. So we learned as Black people to bunch up together and defend each other. And really talk about en la unión está la fuerza. (Milena Sánchez)

Although "Marielitos" were bullied regardless of race, Milena remembers these experiences as tied tightly to her race. She would be directly ridiculed for being Black and did not find a community among other white Cubans:

My very good friends were African American. I also had very good Dominican friends, Puerto Rican friends, but they were all dark skinned. Because the white Latino kids did not care that you spoke Spanish like them. They tried not to speak Spanish around us; that's how I picked up English so quickly. It was out of necessity. Nadie te hablaba. Podía estar en problema, pidiendo ayuda, y te viraban la cara (No one talked to you. You could have a real problem, asking for help, and they would turn their faces). (Milena Sánchez)

Hugo Cancio also remembers being bullied at school for being a "Marielito," but he did not connect his experience to race. As a lighter-skinned mulato, he found friends among white Cubans, many of them other Mariel refugees. Juan Galán recalls living in Little Havana in the 1980s as the only Black Cuban family on Calle Ocho. He would be mistaken for African American, but shared that even as people found out that he was Cuban, they did not always accept him:

I guess growing up there was fun (because we were in the center of everything). But, me and my sister used to fight a lot because ... they looked at us as only Black, you know what I mean? So, a lot of people would talk behind our backs and they didn't know if we spoke the language. From elementary school on down we used to have to defend ourselves. Looking different, I think I fought a few times [at the school where my mother worked] because of them being racist or whatever ... I think kids get programmed by whoever their parents are. So, maybe if their parents might have educated them better, then I wouldn't have had some of the issues I had with the kids growing up. (Galán)

\footnotetext{
30 See Gosin.
} 
Our oral histories both from Mariel refugees and prior show that the Cuban exile community defined themselves as a white community, such that Black Cubans were often mistaken for Black Americans. Many of our participants talk about receiving a certain level of favor once Cubans recognize that they were not African American, but still were never wholly accepted in the white Cuban communities. Julia remembers many instances when she worked in the Miami International Airport when her coworkers would disparage African Americans in front of her:

They are very comfortable. When we worked in TSA and they would say, "ay pero estos negros." And I would say, "hello?" And they would respond, "oh no but you're Hispanic, itss not the same." But if you didn't know me, that's what you'd think of me, so yes, it is the same. They're so comfortable saying these things and they don't understand that it's hurtful. They think it's funny ... To them, white is normal and Black is not so they make fun to try to humanize us. (Sainz and Valdez)

Michael Valdez, whose mother came during Mariel shortly before he was born, talks about the constant tension between Black people and Cubans. The African Americans referred to the Cubans as the "chicos." Michael remembers the "Black vs. white" fights in Coral Gables High School where Cubans were classified as white. Michael is dark-skinned and felt torn between which group he belonged in, but frequently felt closer to the Black population. When his mother came in 1980, she was temporarily housed in the Orange Bowl and was then relocated to Minnesota. Michael spent his first ten years in Minnesota where he did not experience much racial discrimination. When he arrived in Miami in 1992, he experienced far more racism than in Minnesota from fellow Cubans who were white.

The majority of Black Mariel refugees were either placed or went to live with family outside of Miami. ${ }^{31}$ Black families shared that living in the New York metro area or elsewhere were choices that they made to avoid the anti-Black racism in Miami. Thus, it is critical to emphasize that while Miami is widely known as a successful, supportive enclave for Cubans, among Black Cubans, it is also known as a white space that is often anti-Black. The racism remembered by Black Mariel migrants reveals the importance of seeking out racially divergent perceptions and experiences when studying Cuban migration. Failing to do so provides a romanticized view of the Cuban enclave that silences the reality of Miami as a racially exclusive site for some Cubans.

\section{Mariel: Challenging Racial Boundaries}

Black Mariel migrants found that their race often mattered more than their Cubanness once they settled in the United States. The most immediate challenge that Black Cubans faced upon arriving in South Florida was housing. The discrimination that Mariel migrants faced because of the reputation of this wave of migrants increased significantly when migrants were Black. Our oral histories reveal that each Black family employed distinct strategies to not only find homes, but also to enroll their children in the best schools and build community despite persistent anti-Black racism.

Most Black Mariel migrants were not able to rent houses or apartments in white Cuban neighborhoods of Little Havana or Hialeah. Miladys Sánchez was eight years old when her mother packed up her and her two siblings along with her mother's teenage sister and joined the group of Cubans in the Peruvian Embassy. Immigration officials initially sent Sánchez's family to Arkansas, but shortly afterwards her grandmother's sister sponsored them, and they moved to Newark, New Jersey to live with her. By the middle of 1984, her family moved to the Sweetwater neighborhood in Miami. Miladys' mother wanted to escape the cold weather and a friend in Sweetwater facilitated their relocation both in recommending a neighborhood and helping them rent a space. Significantly, Sánchez recalls her mother sending her white friend to rent their apartment knowing that the owners wouldn't rent to a Black family:

MS: As a matter of fact ... that was exactly what happened to my mom in Sweetwater. She had to send those friends of ours [to request the apartment].

DC: Your mother's friends were white?

MS: Yes. Or at least passed as white...

DC: So, you think that that's how she got the apartment that she rented?

MS: Yes. Definitely.

\footnotetext{
${ }^{31}$ See Bach et al.
} 
The Sánchez family only lived in Sweetwater for a short time before moving to a Cuban neighborhood in Kendall where another white relative helped them secure housing. "In the late 80 s when my mom rented over there on 175th, there were a lot of white Cubans ... to get over there, she had to have gotten somebody to [help] ... maybe my stepdad because my stepdad, you know, pasaba por blanco [passed for white], he had wavy hair ... he had green eyes, and he was white" (Miladys Sánchez). Securing housing in the white Cuban space not only meant better rentals, but it also meant more educational opportunities.

The majority of our Miami interviewees discussed similar experiences when trying to rent in Cuban neighborhoods both in the 1970s and the 1980s. The unavailability of housing for Black Cubans both before and during Mariel was never a secret—multiple interviewees describe the same process: families would call and speak in Spanish asking about an apartment listing, the owner or property manager would say that it was vacant, and when they arrived, they would make an excuse and say that it was not available. Sending a white or lighter-skinned friend, co-worker, or relative became a strategy that some Black families used to obtain housing. While this shows the existence of interpersonal cooperation between Black and some white Cubans, it does not diminish the larger structural anti-Black racism that met Black Cubans upon arrival in Miami.

Even when Black Mariel migrants were able to obtain housing in white Cuban neighborhoods, they were often the only Black family to do so, which limited their social interactions. Hugo Cancio remembers "We were the only Black family in South Beach. We were the only Black family in Hialeah." Both Sánchez and Cancio describe their experiences in these white Cuban neighborhoods as alienating and remember fondly the moment they discovered other Black Cubans living in the Northwest neighborhoods of Allapattah and Brownsville. ${ }^{32}$ The Cancios are mulatos, however, and likely were able to move to Hialeah and South Beach because they were lighter-skinned. None of our darker-skinned interviewees were able to live in these areas and Hialeah continues to be 94\% white and Cuban according to the 2010 Census. Often the possibilities to move out of African American boundaries were facilitated by light skin. Ezequiel Torres shared that his experiences with police abuse in Hialeah at the hands of white Cubans confirmed that he would never live in Hialeah. He says, "and the police, you see that they are predisposed to stop you solely because you are black" (Torres). As Sergio Arrechea recalls, "Black Cubans came to Little Havana during the day because at night they lived in Carol City or Allapattah," which were both African American neighborhoods like Overtown.

\section{Black Mariel Migrants: Building Community}

Black migrants that arrived during the Mariel boatlift were introduced to a well-established, yet small Black Cuban community that built racial solidarity over the previous two decades. ${ }^{33}$ Those that arrived in the 1960s and 70s cultivated a close-knit community that continues to exist today. The closeness of these families was an exceptional consequence of racial exclusion. Black families moved into African American neighborhoods because their race did not allow them to live near their co-ethnics, but the cultural and language barriers were sometimes difficult to overcome. Similarly, while Black Cubans still ate and shopped in Little Havana, their relationships with white Cubans and their access to their spaces were limited because of race as well. These unstable positions between two communities meant that they held onto each other and relied on each other for social outlets, religious practice, and shared language of what it meant to be Black and Cuban in Miami.

Miladys Sánchez recalls how she was first introduced to this community and what it meant to her having lived with white Cubans for most of her childhood in Miami:

I remember it was a party in the Northwest area and I can recall that's one of the first parties that I went to where I saw all of these Black Cubans. And then I heard the rumba and I swear, to me it felt like it was almost in my blood. I wanted more of it. And basically, that's when I started my path of learning more about Black Cubans.

She later says, "It was like to me, I felt at home. And again, not because of the area but just the fact that there were other Black Cubans" (Miladys Sánchez). Although Sánchez found this community later in her teens, these communities lived and celebrated together for decades before her arrival. Cancio also remembers first discovering the Black Cuban community and attending religious events in Allapattah: "I'm like, 'what the, what's

\footnotetext{
32 Our oral histories show that Black Cubans also lived in Liberty City, Carol City and North Miami.

33 Mark Sawyer estimated that less than 3\% of the first two waves of Cuban exiles (1959-1962 \& 1965-1973) were Black and Pedraza notes that by $1970,9-13 \%$ of Cubans described themselves as nonwhite, but this likely includes nonblack Cubans.
} 
going on here?' when I saw them. I made a lot of Black Cuban friends who I still speak to today. But I didn't realize they were [there]. They were somewhere in Northwest. Allapattah ... I went to toque de santos there ... I started visiting them" (Cancio and Cancio). The surprise that resulted from meeting Black Cuban communities for the first time is a consequence of the residential segregation in Miami. White Cuban communities were separated from Black neighborhoods and those who were able to secure housing in these Cuban communities were isolated from their racial group as a result. Julia Sainz, whose mother came during Mariel and grew up in the Shenandoah area, also described having little to no contact with other Black Cubans. When she met her husband, Michael, he was part of a strong community in the Northwest area of Allapattah while living with his madrina (godmother in the Yoruba religion). She was as surprised as other interviewees to meet people that "looked like her" (Sainz and Valdez). When I asked Michael if his madrina had a Black Cuban network, he responded: "I would say so. It was more like a religious thing — with Santeria/Yoruba religion. There were a lot of Black Cubans that would congregate together. That community was really strong. They lived in different places ... they came together to do ceremonies ... everyone knew each other" (Sainz and Valdez). The Northwest area, particularly in Allapattah, was not only a residential hub for many Black Cubans but a hub for gatherings, quinceañeras, religious ceremonies, and overall community. Indeed, in the late 1960s, David Rosemond's family, after countless rejections from white Cubans in Southwest neighborhoods, was able to purchase their first house in Allapattah. The house was purchased from a Jamaican homeowner and slowly these predominantly Black American neighborhoods became spaces for Black Cubans and other Black immigrants to carve out a community.

Experiences of exclusion and the building of Black Cuban communities created different identity politics for Black Mariel migrants. Miladys Sánchez, one of the youngest Mariel migrants to arrive in the United States at only age eight, attended elementary, middle, and high school in the Kendall neighborhood of Miami. She recalls mostly white Cubans in her class giving the feeling that she did not fit into celebrations for either Black or Hispanic Heritage month.

When it was Black history month, they wanted to say, "oh you're not Black, you're Latina." Or, that wasn't really the word that I remember, but just the fact that I spoke Spanish and I spoke broken English, they could tell by my accent, so they knew that I wasn't born here. You know? And then when it was Hispanic Heritage Month, I couldn't be around them, it's like, oh you're Black. (Miladys Sánchez)

But maybe more jarring than not fitting into these celebrations at her predominantly white schools was the frequency with which white Cubans called Sánchez "nigger":

MS: I wouldn't really remember if she was Cuban or not. I remember that she was Spanish though ... she called me a nigger. And that was the first time that I've heard that.

DC: In English?

MS: Sí, en inglés. So, para mi fue una sorpresa [for me it was a surprise], but I didn't know. In school you hear that from all the kids. And it's like, I'm not, like I don't consider myself....I actually felt insulted that she called me that because no, I'm Cuban. You don't realize, but thinking about it now ... you can't consider yourself Cuban when you're among certain people ... Because, they don't see you as that. They just see you as negra.

DC: Did you tell your mother about it?

MS: No, no. Another time, I remember it was the kids on the bus, and that was in Marjory Stoneman Douglas [school]. I used to walk home, and I was walking home, and the kids were passing in the bus, and they yelled it [nigger] out. I felt so hurt, oh my god, like every time that I even think about it now, it hurts me so bad. I tried to act like I didn't hear it, you know what I mean? I tried to act like it wasn't [me they were talking to], because I'm Cuban. You know what I mean? Like, they couldn't be calling me that, like, how dare they? They must be talking to, you know a Black American, not me. I'm like, who, who the hell do they think I am?

DC: They were Cuban?

MS: Yea ... and they thought it was a joke, I remember they were laughing, you know. They thought it was something funny. But then, as you get older, you don't think that it's going to happen when you're in middle school. You don't think it's going to happen when you're in high school because you're getting older and kids are more [mature] ... [they know] you can't say this around certain people or whatever. And it still happened ... And, in a sense, [it was like] the Hispanic Heritage month. Where do I belong? (Miladys Sánchez) 
Experiences like these were not only traumatic for a young Sánchez; they also pushed her toward finding a Black Cuban community and developing her own political activism that was distinct from that of white Cubans. Through these experiences, Sánchez recognized that she would never be just Cuban to white Cubans and began to develop her own Black Cuban consciousness. Since May 2015, Sánchez has had an Instagram account and Facebook page called Nubian Cuban, where she shares and celebrates Black Cuban history. She was featured in the May edition of the transnational Afrocubana magazine and has not only fully embraced being both Black and Cuban but seeks to educate and liberate other Black people as well. ${ }^{34}$

Hugo Cancio, who has built spaces for Black Cubans through entertainment, recognizes that he does not have the same politics as white Cubans. He says he might have developed those same anti-Castro attitudes if he had gone to a school like Belén, a private school for upper-middle-class Cuban boys. "Then I would have been influenced by a different type of politics ... I was never very much into politics ... I didn't follow local television. I didn't listen to Spanish music" (Cancio and Cancio). When asked what type of music he listened to growing up, he said, "Earth, Wind, and Fire. I listened to Motown" (Cancio and Cancio). Cancio had access to U.S. Black music because he grew up in the tourist town of Varadero surrounded by Black entertainers and musicians. These ideas traveled with Cancio and his family to South Florida and made them more open to building community with Black Americans and Black Cubans. Cherie Cancio noted that "her whole family [on the Cuban side] are Democrats" and very liberal, making her a minority among her Cuban peers in high school $^{36}$ (Cancio and Cancio). Both the Sánchez and Cancio oral histories highlight the ways Black Mariel migrants joined and expanded an existing, thriving Black Cuban community that was more left-leaning and socially active around racial issues than the dominant white Cuban enclave.

Looking at politics and community building among Black Mariel migrants reveals that race often trumped political conservatism in relation to white Cubans and their politics. In this way, our oral histories demonstrate how racial group membership matters for Cuban politics, in ways that have not yet been explored in the literature. As David Rosemond, a 1960s Black immigrant, commented about his partisanship being met with shock by fellow Cuban exiles, "I'm a Democrat. Yes, I'm Cuban, but I'm also Black." Here we not only find that Black Cubans are more likely to be Democrats, but the connection to the Democratic party grew stronger with the election of Barack Obama. Even among those that were socialized into voting Republican by larger white Cuban communities, many of our oral history participants stated that once Barack Obama ran for office, they abandoned their party loyalty and chose racial solidarity. These decisions were not just based on the color of one's skin, but the experience that comes with being Black and Cuban, mirroring Black American political behavior. Black Cubans created alternative enclave communities, pushed for access and inclusion, and spoke out against discrimination in their new home.

\section{Conclusions: Continuity Across the 1980 Divide of Cuban Immigrants}

Traditionally, the dominant narrative maintains that race only mattered in the Cuban exile community after 1980 and the Marial Boatlift. Our oral histories show consistency between Black Cuban experiences in Cuba, in 1960s and 1970s Miami, and Mariel. The persistence of anti-Black racism in the white Cuban enclave excluded Black Cubans from the start of post-1959 migration and continued through the migration of those who left via Mariel. It is important to recognize that the stigma that Blackness created among the Mariel migrants did not only affect perception: there were real life consequences of marginalization that created less opportunity for Black folks coming to Miami in 1980 when compared to white migrants of this same wave. By ignoring these realities and writing about Black people solely as percentages among a whole, scholars privilege whiteness even among Mariel refugees who were racially stigmatized. Understanding how race and racism weave through access, opportunity, and socialization is crucial to fully tell the stories of Cuban migration to the United States.

Our partial aim for this project is not only to show how Black migrants were excluded, but to celebrate Black community and strategies to overcome exclusion. As Milena Sánchez shares, her mother always told her:

\footnotetext{
${ }^{34}$ Mark Sawyer estimated that less than 3\% of the first two waves of Cuban exiles (1959-1962 \& 1965-1973) were Black and Pedraza notes that by $1970,9-13 \%$ of Cubans described themselves as nonwhite, but this likely includes nonblack Cubans.

${ }^{35}$ Miladys Sánchez, "Miladys." Afrocubanas: La revista, May 6, 2002, afrocubanas.com/2021/05/02/miladys/?fbclid=IwAR34B6QTb fdvHvAIFfvo0XjFKnkZ2c-1SHFxa3LuZ_C82h500VgRh_7TV_g.

${ }^{36}$ Cherie Cancio continued her minority view of politics among Cubans after High School and founded Cuba One Foundation, which sponsors high-impact trips to Cuba for Cuban Americans to reconnect with their heritage and families.
} 
Estudie (study), become a professional, para tener una vida linda (a beautiful life). Date a respetar. You know? So eso siempre estuvo ahí (that was always there) ... Y ella me apoyó muchísimo (and she supported me so much). Si no fuera por su apoyo (if it weren't for her support), I wouldn't be a professional today. I wouldn't be. And the other thing is if I believed everything everyone told me, I wouldn't be. You have to have a very strong foundation at home.

By the time Mariel migrants arrived in Miami, Black Cubans could join existing Black communities in Allapattah and elsewhere and even rent from Black Cubans who had arrived before them as Arrechea's story shows. Today, Black Cubans continue to construct community around the solidarity first maintained decades ago and second-generation Cubans benefit from the closeness of Black Cubans, the familiarity of cultural sharing, and the access, albeit often outside of the white Cuban community, that their success has earned them. Each participant in these oral histories that came during Mariel has carved a distinct space for themselves, often around Black cultural affirmation. This in itself is a story that must be told as we re-read, and rewrite, the history of Cuban migration.

\section{Acknowledgements}

This work has been supported (in part) by Grant \# 1911-19132 from the Russell Sage Foundation. Any opinions expressed are those of the principal investigator(s) alone and should not be construed as representing the opinions of the Foundation.

\section{Competing Interests}

The authors have no competing interests to declare.

\section{References}

Aguirre, Benigno E. "Differential Migration of Cuban Social Saces: A Review and Interpretation of the Problem." Latin American Research Review, vol. 11, no. 1, 1976, pp. 103-124.

---. Cuban Mass Migration and the Social Construction of Deviants." Bulletin of Latin American Research, vol. 13, no. 2, 1994, pp. 155-183. DOI: https://doi.org/10.2307/3338273

Arrechea, Sergio. "Sergio Arrechea oral history interview conducted by Danielle Clealand. in Miami, Florida, 2019-03-19." Translated from Spanish by Devyn Benson and Danielle Clealand.

Aja, Alan A. Miami's forgotten Cubans: Race, Racialization, and the Miami Afro-Cuban experience. Springer, 2016. DOI: https://doi.org/10.1057/978-1-137-57045-1

Bach, Robert L., Jennifer B. Bach, and Timothy Triplett. "The Flotilla "Entrants": Latest and Most Controversial/El éxodo de los "marielitos": el más reciente y de mayor controversia." Cuban Studies, vol. 11, no. 2, 1981, p. 29.

Benson, Devyn Spence. Antiracism in Cuba: The Unfinished Revolution. UNC Press Books, 2016. DOI: https:// doi.org/10.5149/northcarolina/9781469626727.001.0001

Boswell, Thomas D., and James R. Curtis. The Cuban-American Experience. Culture, Images and Perspectives. Rowman \& Allanheld, 1984.

Brown, Leslie, and Anne Valk. Living with Jim Crow: African American Women and Memories of the Segregated South. Springer, 2010.

Burga, Hector Fernando. "The Mariel Boatlift and Comprehensive Planning: Humanitarian Crisis, Demographic Data, and Cuban-American Community Development." Planning Perspectives, vol. 36, no. 3, 2021, pp. 433-449. DOI: https://doi.org/10.1080/02665433.2020.1779793

Cancio, Hugo, and Cherie Cancio. "Hugo Cancio and Cherie Cancio oral history interview conducted by Danielle Clealand. in Miami, Florida, 2019-02-12."

Card, David. "The Impact of the Mariel boatlift on the Miami Labor Market." ILR Review, vol. 43, no. 2, 1990, pp. 245-257. DOI: https://doi.org/10.1177/001979399004300205

Casanova, Manuel. "Manuel Casanova oral history interview conducted by Danielle Clealand. in Miami, Florida, 2019-10-28." Translated from Spanish by Devyn Benson and Danielle Clealand.

Clark, Juan M., Jose I. Lasaga, and Rose S. Reque. The 1980 Mariel Exodus: An Assessment and Prospect. Council for Inter-American Security, 1981.

Clealand, Danielle Pilar. The Power of Race in Cuba: Racial Ideology and Black Consciousness During the Revolution. Oxford University Press, 2017. DOI: https://doi.org/10.1093/oso/9780190632298.001.0001

de los Angeles Torres, Maria. In the Land of mirrors: Cuban Exile Politics in the United States. University of Michigan Press, 2001. 
Eckstein, Susan. The Immigrant Iivide: How Cuban Americans changed the US and their homeland. Routledge, 2009.

---. The Mariel Exodus Twenty Years Later: A study on the Politics of Stigma and a Research Bibliography. Ediciones Universal, 2002.

Flores, Juan, and Miriam Jiménez Román. "Triple-consciousness? Approaches to Afro-Latino Culture in the United States." Latin American and Caribbean Ethnic Studies, vol. 4, no. 3, 2009, pp. 319-328. DOI: https://doi.org/10.1080/17442220903331662

Galán, Juan. "Juan Galán oral history interview conducted by Danielle Clealand in Miami, Florida, 2019-04-19."

García, María Cristina. Havana USA: Cuban Exiles and Cuban Americans in South Florida, 1959-1994. Univ of California Press, 1996.

Gastón Fernández. "Race, Gender, and Class in the Persistence of the Mariel Stigma Twenty Years After the Exodus from Cuba." International Migration Review, vol. 41, no.3, 2007, pp. 602-622. DOI: https://doi. org/10.1111/j.1747-7379.2007.00087.x

González, Ricardo. "Ricardo González oral history interview conducted by Devyn Benson and Danielle Clealand. in Miami, Florida, 2018-12-07."

Gosin, Monika. The Racial Politics of Division. Cornell University Press, 2019. DOI: https://doi.org/10.7591/ cornell/9781501738234.001.0001

Goudsouzian, Aram, and Charles W. McKinneyJr, eds. An Unseen Light: Black Struggles for Freedom in Memphis, Tennessee. University Press of Kentucky, 2018. DOI: https://doi.org/10.2307/j.ctt2111h1m

Grenier, Guillermo J., and Alex Stepick, editors. Miami Now!: Immigration, Ethnicity, and Social change. University press of Florida, 1992.

Gugliotta, Guy. "New Exiles Younger than Ever; Blue-Collar Men Crowd Refugee Ranks." Miami Herald, 11 May 1980, p. 21-A.

Hamm, Mark S. The Abandoned Ones: The Imprisonment and Uprising of the Mariel Boat People. Upne, 1995.

Hanly, Elizabeth. "Santería discussion stirs up passions." The Miami Herald (italicized), 17 Apr 2004, p. 221.

Honey, Michael K. Black Workers Remember: An Oral History of Segregation, Unionism, and the Freedom Struggle. Univ of California Press, 2002.

López, Antonio. "Cosa de Blancos: Cuban-American Whiteness and the Afro-Cuban-Occupied House." Latino Studies, vol. 8, no. 2, 2010, pp. 220-243. DOI: https://doi.org/10.1057/lst.2010.23

López, Maria. "Maria López oral history interview conducted by Devyn Benson and Danielle Clealand in Miami, Florida, 2019-06-14." Translated from Spanish by Devyn Benson and Danielle Clealand.

Masud-Piloto, Felix Roberto. From Welcomed Exiles to Illegal Immigrants: Cuban Migration to the US, 19591995. Rowman \& Littlefield, 1996.

Pedraza, Silvia. "Los Marielitos of 1980: Race, Class, Gender and Sexuality." Cuba In Transition, 2004, pp. 89-102.

Perks, Robert, and Alistair Thomson. "Oral History Reader, The [Book Review]." 1998, pp. 62-63.

Portes, Alejandro, Juan M. Clark, and Robert D. Manning. "After Mariel: A Survey of the Resettlement Experiences of 1980 Cuban Refugees in Miami/Después del Mariel: una encuesta de las experiencias del asentamiento de los refugiados cubanos de 1980 en Miami." Cuban Studies, vol. 15, no. 2, 1985.

Portes, Alejandro, and Alex Stepick. "Unwelcome immigrants: The Labor Market Experiences of 1980 (Mariel) Cuban and Haitian Refugees in South Florida." American Sociological Review, 1985, pp. 493-514. DOI: https://doi.org/10.2307/2095435

Rosemond, David. "David Rosemond oral history interview conducted by Danielle Clealand in Miami, Florida, 2018-10-31."

Rosemond, Deborah. "Deborah Rosemond oral history interview conducted by Devyn Benson and Danielle Clealand in Miami, Florida, 2019-06-13."

Sainz, Julialeida and Michael Valdez. "Julialeida Sainz and Michael Valdez oral history interview conducted by Danielle Clealand in Miami, Florida, 2019-11-09."

Salkey, Andrew. Havana journal. Vol. 1303. Penguin, 1971.

Sánchez, Miladys. "Miladys Sánchez oral history interview conducted by Danielle Clealand in Miami, Florida, 2019-03-21."

Sánchez, Milena. "Milena Sánchez oral history interview conducted by Danielle Clealand in Miami, Florida, 2019-04-05." 
Sawyer, Mark Q. Racial Politics in Post-Revolutionary Cuba. Cambridge University Press, 2006. DOI: https:// doi.org/10.1017/CBO9780511791031

Skop, Emily H. "Race and Place in the Adaptation of Mariel Exiles." International Migration Review, vol. 35, no. 2, 2001, pp. 449-471. DOI: https://doi.org/10.1111/j.1747-7379.2001.tb00025.x

Sierra Madero, Abel. "11. "Here, Everyone's Got Huevos, Mister!"." The Revolution from Within. Michael Bustamante and Jennifer Lambe, editors. Duke University Press, 2019, pp. 244-274. DOI: https://doi. org/10.1515/9781478004325-012

Torres, Luis Ezequiel. "Luis Ezequiel Torres oral history interview conducted by Danielle Clealand. in Miami, Florida, 2019-04-25." Translated from Spanish by Devyn Benson and Danielle Clealand.

Triay, Victor Andres. The Mariel Boatlift: A Cuban-American Journey. University of Florida Press, 2019.

Walmsley, Anne. The Caribbean Artists Movement, 1966-1972. New Beacon Books, 1992.

Yow, Valerie Raleigh. Recording Oral History: A Guide for the Humanities and Social Sciences. Rowman \& Littlefield, 2014.

How to cite this article: Benson, D and Clealand, D 2021 Re-Narrating Mariel: Black Cubans, Racial Exclusion, and Building Community in Miami. Anthurium, 17(2): 6, 1-17. DOI: https://doi.org/10.33596/anth.462

Published: 14 December 2021

Copyright: $\odot 2021$ The Author(s). This is an open-access article distributed under the terms of the Creative Commons Attribution 4.0 International License (CC-BY 4.0), which permits unrestricted use, distribution, and reproduction in any medium, provided the original author and source are credited. See http://creativecommons.org/licenses/by/4.0/. 